\title{
The Impact of Capital and Deposit on Financial Performance of Commercial Banks in Nepal
}

\author{
Dhundi Raj Bhattarai, Ph. D. ${ }^{1}$ \\ (dhundibhattarai@gmail.com)
}

\begin{abstract}
Purpose of this study is to measure characteristics of core capital ratio, bank capital, deposit, net profit after tax, and earnings per share and their separate relationship and measure the individual impact of core capital ratio, bank capital, and deposit on financial performance i.e., net profit after tax (NPAT) and earnings per share (EPS). Descriptive, correlational, and casual comparative research design has been used in this study. This study analyzed secondary data of twenty-six commercial banks from fiscal year 2012/13 to 2018/19 out of twenty-seven. Descriptive statistics, correlation analysis, and regression analysis statistical tools were used in this study. According to its findings, earnings per share is highly dispersed in comparison to net profit after tax as well as core capital ratio than bank capital. There is high degree of positive relationship in between net profit after tax and deposit. Low degree of positive relation in NPAT and core capital ratio and moderate degree of positive relation in NPAT and Bank capital. Low degree of positive relation of EPS with deposit and low degree of inverse relation of EPS with core capital. Core capital ratio, bank capital, and deposit positive effects for increasing NPAT. Out of its, deposit highly effect. Deposit positive effects for increase on EPS. High contribution of deposit and core capital to increase net profit. The results of this study have relevance and probable generalizability about the impact of capital adequacy ratio and deposit to increase financial performance of commercial banks in Nepal.
\end{abstract}

Keywords: NPAT, EPS, Capital, Deposit, Commercial banks

\section{Introduction}

Bank deposits consist of money placed into the Bank by its customers. These deposits are made to deposit accounts such as fixed deposit accounts, savings accounts, margin deposit accounts, call deposit accounts and current accounts. Deposits and borrowings (debt securities issued) are the source of funds of the bank in addition to its reserves.

European Banks with higher deposits and loans ratio tend to be more profitable but the effects on profitability are statistically insignificant in some cases (Menicucci \& Paolucci, 2016). Deposits and borrowings (including debts securities issued) are initially measured at fair value minus incremental direct transaction cost and subsequently measured at their

1 Lecturer, Nepal Commerce Campus, T. U.

9851126796 
amortized cost using the effective interest method, except where the Bank designates liabilities at fair value through profit or loss. a significant and negative correlation between the liquidity creation and performance of Islamic banks, using return on average equity measure (Sahyouni \& Wang, 2019). Need for improving capital adequacy and reducing the ratio of non-interest assets as a way to improve profitability (Husain \& Abdullah, 2008).

Tier-1 Capital has a negative effect to profitability in Indonesian Commercial Banks (Sari, Suhadak, Rahayu, \& Solimun). The capital adequacy ratio (CAR) is a measurement of a bank's available capital expressed as a percentage of a bank's risk-weighted credit exposures. The capital adequacy ratio, also known as capital-to-risk weighted assets ratio (CRAR), is used to protect depositors and promote the stability and efficiency of financial systems around the world. Two types of capital are measured: tier-1 capital, which can absorb losses without a bank being required to cease trading, and tier- 2 capital, which can absorb losses in the event of a winding-up and so provides a lesser degree of protection to depositors. The study also revealed that GDP per capita, market capitalization and banks size have no impact on profitability (Ahamad, 2019). perhaps

For two decades, the capital adequacy ratio (CAR) requirement has been one of the primary regulatory mechanisms used to monitor banks. Presently, most regulators around the world follow the Basel Accord, under which CARs are calculated by dividing a firm's regulatory capital (Tier 1, Tier 2, and Tier 3) by the firm's risk-weighted assets (RWAs). However, many banking practitioners and researchers have argued that CARs now have less relevance due to the change from the historical-cost-based accounting regime to the fair-value-based system (Anagnostopoulos and Buckland, 2005). Credit deposit ratio (CRDR) reduced the profitability of private banks and public banks in India (Bansal, Singh, Kumar, \& Gupta, 2018). Specifically, under the former system, balance sheet items were based on the book values of assets and liabilities, while under the latter regime a great portion of financial assets and liabilities (and hence, the regulatory capital) are determined on a marked-to-market basis. As a result, the introduction of fair-value reporting may cause increased "unnecessary" volatility of earnings and thus lead to the decreased relevance of CARs (Chisnall, 2000; Allen and Carletti, 2008; Heaton et al., 2010).

Return on assets, the loans to deposit ratio, the logarithm of personnel, and the logarithm of income of per capita, all have a positive and statistically significant impact on overall efficiency change (Gaganis, Liadaki, Doumpos \& Zopounidis (2009). Application of fairvalue accounting in the Taiwan banking industry is fairly similar to that of international or US GAAP, and using Taiwan data also offers empirical advantages (as mentioned in the previous paragraph), these results also yield insights into other standard-setters (Liao, 2013). Second, a clear policy implication is related to the urgent need to seek feasible measures for mitigating possible negative effects (Liao, 2013). More specifically, since as-if costbased CARs convey superior information at least under some circumstances, requiring the explicit disclosure of cost-based CARs may aid users in assessing banks' insolvency risks. Additionally, users should evaluate banks' disclosure quality before basing economic decisions on fair-value-based CARs. Regulators and standard-setters should make more 
effort to enhance the reporting quality if a full, fair-value application is still the eventual goal for the near future (Liao, 2013).

Capital regulation is an effective tool in enhancing the stability and the profitability of the financial services sector. In addition, the paper finds a positive relationship between regulatory pressure in terms of restrictions on deposits and non-bank financial institutions profitability (Ofoeda, Gariba, \& Amoah, 2016). Risk management is crucial to the banking industry. Since the Basel Accord was introduced, the minimum CAR requirement has become a major regulatory tool in various jurisdictions. By definition, a CAR is the ratio of a bank's total regulatory capital divided by the total amount of RWAs. Regulatory capital consists of three types of capital - Tier 1, Tier 2, and Tier 3 - while RWAs refer to a bank's assets weighted according to credit, interest, and operational risk. Previous studies on CARs mainly center on the influence of the capital requirement on the riskiness of banks. For instance, Shrieves and Dahl (1992) shows that, for banks that were undercapitalized according to regulatory standards, the minimum capital regulation was at least partially effective in forcing banks to increase their capital or to decrease risks. Profitability is positively affected by banks' costeffectiveness, asset quality and level of capitalization in Islamic bank (Zarrouk, Jedidia, \& Moualhi, 2016).

Konishi and Yasudab (2004) finds that implementing the capital adequacy requirement reduced risk taking in Japanese commercial banks; the authors also found that a bank's capital was negatively related to risk taking. Recently, in 2009 in the aftermath of the financial crisis, the Basel Committee on Banking Supervision (BCBS) proposed major revisions and additions to the existing Basel II capital adequacy regime. The resultant proposed framework is termed "Basel III," and the G20 endorsed the new Basel III capital and liquidity requirements at the November 2010 Summit in Seoul. In detail, several important amendments were endorsed. First, banks are required to hold 4.5 percent of common equity (up from 2 percent in Basel II) and 6 percent of Tier 1 capital (up from 4 percent in Basel II) as RWAs, while Tier 3 capital will be phased out completely. Second, Basel III introduces additional capital buffers: a mandatory capital conservation buffer of 2.5 percent; and a discretionary counter cyclical buffer, which allows national regulators to require up to another 2.5 percent of capital during periods of high credit growth.

The liquidity coverage ratio requires a bank to hold sufficient high-quality liquid assets to cover its total net cash outflows over 30 days; the net stable funding ratio requires the available amount of stable funding to exceed the required amount of stable funding over a one-year period of extended stress. Overall, the new requirements under Basel III seek to improve the quality of the capital, increase risk weightings for derivatives and repos, introduce a leverage ratio, and address pro-cyclicality. Therefore, Basel III is expected to have a major impact on the financial institutions, such as: weaker banks being crowded out; significant pressure on banks' profitability; changes in demand from short-term to long-term funding; reduced risk of a systematic banking crisis; and a decrease in lending capacity (Shearman and Sterling, 2011; KPMG, 2012). Capital regulations are complementary and significantly impact on European bank performance (Ayadi, Ayadi, \& Trabelsi, 2019). 
Financial performance of commercial banks is strongly affected by capital adequacy ratio, management efficiency, gross domestic product, liquidity management and assets quality (Gautam, 2018).

Based on above international studies comparative study of impact of core capital, bank capital, and deposit on financial performance is still remaining. So, this is the research gap of the study.

Based on this research gap, following research question has been developed.

1. What is the average value and disperse value of different study variables: like net profit after tax, earning per share, core capital ratio i.e. Common Equity (Tier 1 to Risk Weighted Exposure Ratio), bank capital, and deposit as well as their relationship?

2. What is the impact of core capital ratio, bank capital, and deposit on financial performance?

This study provides contributions in two ways. First one is impact of core capital, bank capital, and deposit on financial performance and second one is which highly effect on financial performance.

\section{Review of Literature}

Recent theory on capital structure is based on the Modigliani and Miller's (1958) influential work on the effect of capital structure on the value of the firm. Their theory assumes perfect markets and perfect competition in which firms operate without taxes or transaction cost and where all relevant information is available without cost. However, these assumptions do not hold in the real world or in practice and factors such as taxes, agency cost, cost of financial distress and information asymmetry are important in explaining the capital structure of firms.

Hutchinson (1995) approved that in more general terms, financial leverage positive effect on the firm's return on equity provided that earnings' power of the firm's assets (the ratio of earnings before interest and taxes is divided by total assets) exceeds the average interest cost of debt to the firm. He justified that the extent to which a firm's earnings' power is likely to remain above the breakeven point and the potential speed or flexibility with which it can adjust its debt usage, if its earnings' power falls below average interest costs, should help to determine the level of debt that the firm is willing to commit itself to at a given point in time.

Profitability of bank-specific, industry-specific and macroeconomic determinants of South Eastern European credit institutions is examined by Athanasoglou, Brissmis, and Delis, (2006). The empirical study has approved that bank size, credit risk and capitalization have influenced on profitability. Regarding of macroeconomic variables, the results are mixed among different countries. 


\subsection{Conceptual framework}

Based on above study gap, following conceptual frame work has been developed.

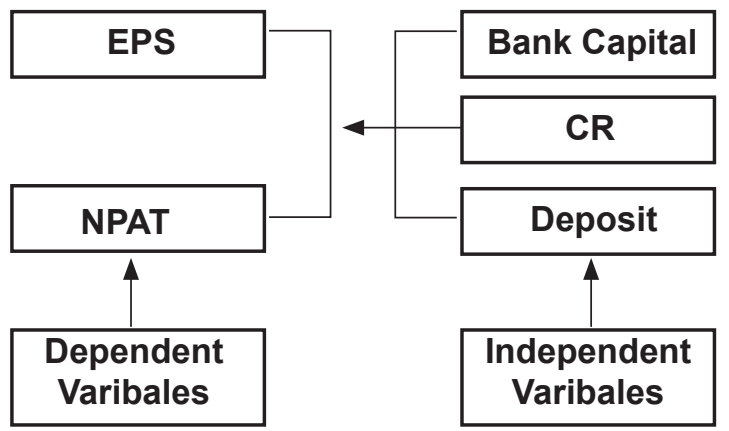

\section{Methodology}

Financial performance was measured through net profit after tax (NFAT) and earning per share (EPS). Secondary sources of data were used in this study. This study occupied twentysix commercial banks out of twenty-seven. Rastriya Banijya Bank was excluded in this study due to lack of annual audit report. Data were collected through annual audit report of respective bank from fiscal year 2012/13 to 2018/19. So, total number of observations were 182. Data were collected from annual audit report of concern bank. Mean, Range, standard deviation, and coefficient of variation statistical tools were used in this study to know individual characteristics of mention variables. So, this study used descriptive research design. Correlation analysis statistical tool was used to understand relationship between different mention variables. Multiple regression analysis statistical tools were used to measure the impact of core capital ratio, bank capital, and deposit on financial performance. So, this study also used correlational and casual comparative research design .

Following regression models were used in this study.

$$
\begin{aligned}
& \mathrm{NPAT}_{i, t}=\alpha_{0}+\beta_{1 C R i, t}+\beta_{2} \mathrm{BC}_{\mathrm{i}, \mathrm{t}}+\beta_{3} \mathrm{DPT}_{\mathrm{i}, \mathrm{t}} \varepsilon_{\mathrm{i}, \mathrm{t}} \ldots \ldots \text {... (i) } \\
& \mathrm{EPS}_{\mathrm{i}, \mathrm{t}}=\alpha_{0}+\beta_{1 \mathrm{CRi}, \mathrm{t}}+\beta_{2} \mathrm{BC}_{\mathrm{i}, \mathrm{t}}+\beta_{3} \mathrm{DPT}_{\mathrm{i}, \mathrm{t}} \varepsilon_{\mathrm{i}, \mathrm{t}} \ldots \ldots \text {.. (i) }
\end{aligned}
$$

Dependent variable is net profit after (NPAT) tax of a firm $i$ in a year $t$ in regression (i) and earning per share (EPS) of a firm $i$ in a year $t$ in regression (ii). Independent variables are core capital ratio (CR) i.e. Common Equity (Tier 1 to Risk Weighted Exposure Ratio, bank capital (BC), and deposit (DPT) of a firm $\mathrm{i}$ in a year $\mathrm{t}$ in both regression model. 


\section{Data Presentation, analysis and results}

\subsection{Descriptive statistics}

Table 1: Descriptive Statistics

\begin{tabular}{|l|c|c|c|c|c|c|}
\hline Variables & $\mathbf{N}$ & Maximum & Minimum & Mean & Std. dev. & C.V. \\
\hline NPAT & 182 & 4238853581.00 & -804628575.00 & 1302411467.05 & 922797094.69 & 70.85296145 \\
\hline EPS & 182 & 198.53 & -40.23 & 27.39 & 19.98 & 72.94633078 \\
\hline CC & 182 & 21.41 & -0.59 & 11.65 & 2.68 & 23.00429185 \\
\hline BC & 182 & 140232067893.00 & 4398193.00 & 9483593013.17 & 11220737437.96 & 118.32 \\
\hline Deposit & 182 & 180575000000.00 & 1126000447.00 & 62606143480.52 & 33819479106.72 & 54.02 \\
\hline
\end{tabular}

Table one has presented that coefficient of variation of earning per share is greater than net profit after tax. Bank capital is highly dispersed than core capital ratio i.e. Common Equity (Tier 1 to Risk Weighted Exposure Ratio). Deposit highly dispersed than core capital ratio and less dispersed than bank capital.

\subsection{Correlation Analysis}

Table 2: Correlation Analysis

\begin{tabular}{|c|c|c|c|c|c|}
\hline Variables & NPAT & EPS & $\mathrm{CC}$ & BC & Deposit \\
\hline NPAT & 1.000 & & & & \\
\hline EPS & $0.424 * *$ & 1.0000 & & & \\
\hline $\mathrm{CC}$ & $0.235^{* *}$ & $-0.229 * *$ & 1.000 & & \\
\hline BC & $0.61 * *$ & 0.119 & $0.37 * *$ & 1.000 & \\
\hline Deposit & $0.86 * *$ & $0.27 * *$ & 0.028 & $0.516^{* *}$ & 1.000 \\
\hline \multicolumn{6}{|c|}{$\begin{array}{l}* * \text {. Correlation is significant at the } 0.01 \text { level (2-tailed } \\
* \text {. Correlation is significant at the } 0.05 \text { level }(2 \text {-tailed }\end{array}$} \\
\hline
\end{tabular}

Table two has presented: Pearson correlation analysis has approved that there is moderate degree of positive relationship in between net profit after tax and bank capital at $1 \%$ LOS. High degree of positive relationship between net profit after tax and deposit at $1 \%$ LOS. Similarly, low degree of positive relationship at $1 \%$ LOS in between net profit after tax and earning per share as well as net profit after tax and core capital ratio. There is low degree of inverse relationship between earning per share and core capital ratio but low degree of direct relationship in between earning per share and deposit at $1 \%$ LOS. Low degree of positive relationship in between core capital ratio and bank capital ratio at $1 \%$ LOS and moderate degree of positive relationship in between bank capital and deposit at $1 \%$ LOS. 


\subsection{Regression analysis}

Table 3: Dependent variable is Net Profit After Tax

\begin{tabular}{|c|c|c|c|c|c|c|c|c|c|}
\hline \multirow{2}{*}{$\begin{array}{c}\text { Models } \\
\text { Variables }\end{array}$} & \multicolumn{3}{|c|}{ Model 1} & \multicolumn{3}{|c|}{ Model 2} & \multicolumn{3}{|c|}{ Model 3} \\
\hline & $\begin{array}{l}\text { Std. } \\
\text { Corff. }\end{array}$ & VIF & T value & $\begin{array}{l}\text { Std. } \\
\text { Corff. }\end{array}$ & T val. & VIF & $\begin{array}{l}\text { Std. } \\
\text { Corff. }\end{array}$ & T val. & VIF \\
\hline Constants & & & -6.524 & & -2.081 & & & -4.755 & \\
\hline $\mathrm{CCi}, \mathrm{t}$ & $0.211 *$ & 1.001 & 6.061 & & & & $0.157^{*}$ & 4.237 & 1.208 \\
\hline $\mathrm{BCi}, \mathrm{t}$ & & & & $0.227^{*}$ & 5.516 & 1.363 & $0.151 *$ & 3.496 & 1.645 \\
\hline Depositi & $0.854 *$ & 1.001 & 24.521 & $0.742 *$ & 18.004 & 1.363 & $0.777 *$ & 19.306 & 1.422 \\
\hline \multicolumn{4}{|l|}{$\mathrm{R} 2=0.783$} & \multicolumn{3}{|c|}{ R $2=0.777$} & \multicolumn{3}{|c|}{ R $2=0.797$} \\
\hline \multicolumn{4}{|c|}{$\mathrm{F}=323.481 *$} & \multicolumn{3}{|c|}{$\mathrm{F}=311.416^{*}$} & \multicolumn{3}{|c|}{$\mathrm{F}=233.251 *$} \\
\hline \multicolumn{4}{|c|}{ D.W. $=2.072$} & \multicolumn{3}{|c|}{ D.W. $=2.156$} & \multicolumn{3}{|c|}{ D.W. $=2.075$} \\
\hline \multicolumn{10}{|c|}{ Signific } \\
\hline
\end{tabular}

Table three has showed: all regression models are statistically significant at $1 \%$ LOS. Value of variation inflation factor (VIF) of each independent variable of three regression models is less than 10 approved that all regression models are free from multicollinearity problem. Value of D.W. at 182 no. of observations approved that all regression models are free from autocorrelation problem. Similarly, all regression models are free from heteroscedasticity problem. More than $78 \%$ area has explained each regression model. Coefficient value of independent variable of each regression model is positive and statistically significant at $1 \%$ LOS. In regression model 1, coefficient value of Deposit 0.854 indicates that, when Deposit variable will be increased by one unit under the condition of other thing will remain the same on an average net profit after tax will be increased by 0.854 unit. Out of three independent variables base on analysis of three regression models Deposit highly positive effect, core capital ratio medium positive effect, and bank capital low positive effect for increasing net profit after tax.

Table 4: Dependent variable is Earning Per Share

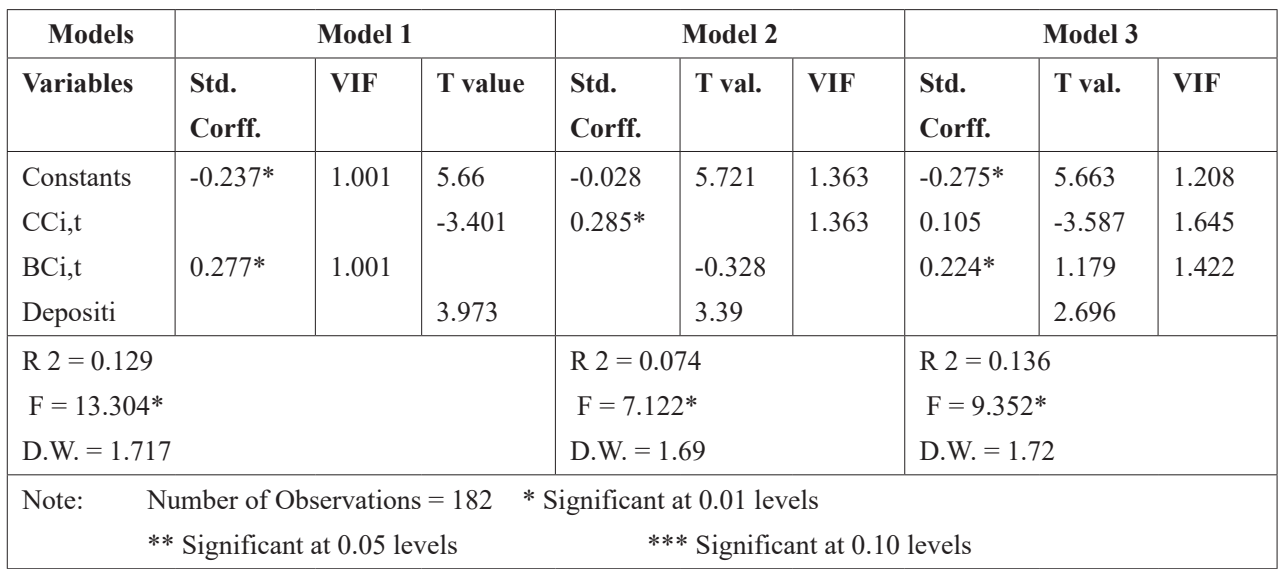


Table four has presented that all regression models are statistically significant at $1 \%$ LOS. All regression models are free from multicollinearity, autocorrelation, and heteroscedasticity problem. All models are statistically significant at 1\% LOS. According to regression result, deposit positive effect for increasing earnings per share but core capital negative effect on earnings per share.

\section{Discussion and Concluding Remarks}

Dispersion rate of core capital ratio (Tier 1 to Risk Weighted Exposure Ratio) is minimum than bank capital. Dispersion rate of deposit is greater than core capital ratio but less than bank capital. Out of earnings per share and net profit after tax, earnings per share is more fluctuated. Net profit after tax low degree of direct relation with earnings per share and core capital, moderate degree direct relation with bank capital, and high degree direct relation with deposit at $1 \%$ LOS. There is low degree of direct relation between deposit and earning per share but low degree of inverse relation of earning per share with core capital. Deposit positive effects on financial performance of commercial banks in Nepal. this result is similar with Menicucci and Paolucci, (2016) and disimilar with Sahyouni and Wang (2019). Core capital ratio and bank capital ratio positive effect to increase net profit after tax. This result is supported by Husain and Abdullah, (2008). Core capital ratio inverse impact on earnings per share. This result is similar with (Sari, Suhadak, Rahayu, \& Solimun). There is no significant impact of bank capital on earnings per share.

This research findings supported on existing theory capital adequacy ratio and deposit effect on financial performance on financial institution. This study has provided the knowledge of commercial banks about impact of different capital as well as deposit. This study based on seven fiscal years from fiscal years 2012/13 to 2018/19 of twenty-six commercial banks. Number of observations are 182 . No. of observation should be increased to measure the impact of bank capital on earnings per share. Dimension of financial performance should be increased i.e., to measure the impact of core capital ratio, bank capital, deposit on return on assets, return on equity, net profit divided by total income, price earning ration etc. Core capital ratio should be increased for decreasing risk and increase net profit margin. Commercial banks of Nepal should be focused on deposit amount. 


\section{References}

Ahmad, A. (2019). The determinants of conventional banks profitability in developing and underdeveloped OIC countries. Journal of Economics, Finance and Administrative Science, https:// doi.org/10.1108/JEFAS-05-2018-0043

Allen, F. and Carletti, E. (2008). Mark-to-market accounting and liquidity pricing. Journal of Accounting and Economics, 45 (2/3), pp. 358-78.

Anagnostopoulos, Y. and Buckland, R. (2005). Historical cost vs. fair value accounting in banking. Journal of Banking Regulation, Vol. 6 No. 4, pp. 109-27.

Athanasoglou, P.P., Brissmis, S.N. and Delis, M.D. (2008). Bank-specific, industry-specific and macroeconomic determinants of bank profitability. Journal of International Financial Markets, Institutions and Money, Vol. 18 No. 2, pp. 121-36.

Ayadi, A. Ayadi, N. and Trabelsi, S. (2019). Corporate governance, European bank performance and the financial crisis. Managerial Auditing Journal, https://doi.org/10.1108/ MAJ-11-2017-1704 Permanent link to this document: https://doi.org/10.1108/MAJ-11-2017-1704

Bansal, R. Singh, A. Kumar, S. Gupta, R. (2018). Evaluating factors of profitability for Indian banking sector: a panel regression. Asian Journal of Accounting Research, https:// doi.org/10.1108/AJAR08-2018-0026

Chisnall, P. (2000). Fair value accounting: an industry view. British Bankers' Association, Balance Sheet, Vol. 9 No. 1, pp. 27-33.

Gaganis, C. Liadaki, A. Doumpos, M. and Zopounidis, C. (2009). Estimating and analyzing the efficiency and productivity of bank branches. Managerial Finance, Vol. 35 Iss 2 pp. 202 - 218 http://dx.doi.org/10.1108/03074350910923518

Gautam, R. (2018). Determinants of financial performance: An evidence from Nepalese commercial bank. Amity Journal of Strategic Management, 1(2), 7-13.

Heaton, J.C., Lucas, D. and McDonald, R.L. (2010). Is mark-to-market accounting destabilizing? Analysis and implications for policy. Journal of Monetary Economics, Vol. 57 No. 1, pp. 64-75.

Husain, A. Abdullah, A. (2008). Bank-Specific Determinants of Profitability: The case of Kuwait. Journal of Economic and Administrative Sciences, Vol. 24 Iss 2 pp. 20 - 34 http://dx.doi. org/10.1108/10264116200800006

Hutchinson, R.W. (1995). The capital structure and investment decisions of the small owner-managed firm: some explanatory issues. Small Business Economics, Vol. 7, p. 231.

Konishi, M. and Yasudab, Y. (2004). Factors affecting bank risk taking: evidence from Japan. Journal of Banking \& Finance, Vol. 28 No. 1, pp. 215-32.

KPMG (2012). Basel III: issues and implications", available at: www.kpmg.com/global/en/ issuesandinsights/articlespublications/frontiers-in finance/ publishingimages/ february 2012/ february2012/21010.html

Liao, Y (2013). The impact of fair-value-accounting on the relevance of capital adequacy ratios Evidence from Taiwan. Managerial Finance, Vol. 39 No. 2, 2013 pp. 133-154 q Emerald Group Publishing Limited 0307-4358 DOI 10.1108/03074351311293990

Menicucci, E. Paolucci, G. (2016). The determinants of bank profitability: empirical evidence from European banking sector. Journal of Financial Reporting and Accounting, Vol. 14 Issue: 1, pp.86115, https://doi.org/10.1108/JFRA-05-2015-0060 
Ofoeda, I. Gariba, P. Amoah, L. (2016). Regulation and performance of non bank financial institutions in Ghana. International Journal of Law and Management, Vol. 58 Iss 1 pp. 108 - 125 http:// dx.doi.org/10.1108/IJLMA-11-2014-0060

Modigliani, F. and Miller, M. (1958). The cost of capital, corporation finance and the theory of investment. The American Economic Review. Vol. 48 No. 3, pp. 261-97.

Shearman and Sterling (2011). The new Basel III framework: implications for banking organizations. Financial Institutions Advisory \& Financial Regulatory.

Shrieves, R.E. and Dahl, D. (1992). The relationship between risk and capital in commercial banks. Journal of Banking \& Finance, Vol. 16 No. 2, pp. 439-57.

Sahyouni, A. and Wang, M. (2019). Liquidity creation and bank performance: evidence from MENA. ISRA International Journal of Islamic Finance, https://doi.org/10.1108/IJIF-01-2018-0009 Permanent link to this document: https://doi.org/10.1108/IJIF-01-2018-0009

Sari, E. Suhadak, S. Rahayu, S. M. and Solimun, S. The effects of Tier-1 capital, risk management, and profitability on performance of Indonesian commercial banks. International Journal of Law and Management, https:// doi.org/10.1108/IJLMA-05-2017-0109

Zarrouk, H. Jedidia, K. B. Moualhi, M. (2016). Is Islamic bank profitability driven by same forces as conventional banks? International Journal of Islamic and Middle Eastern Finance and Management, Vol. 9 Iss 1 pp. 46 - 66 http://dx.doi.org/10.1108/IMEFM-12-2014-0120 


\section{Appendix}

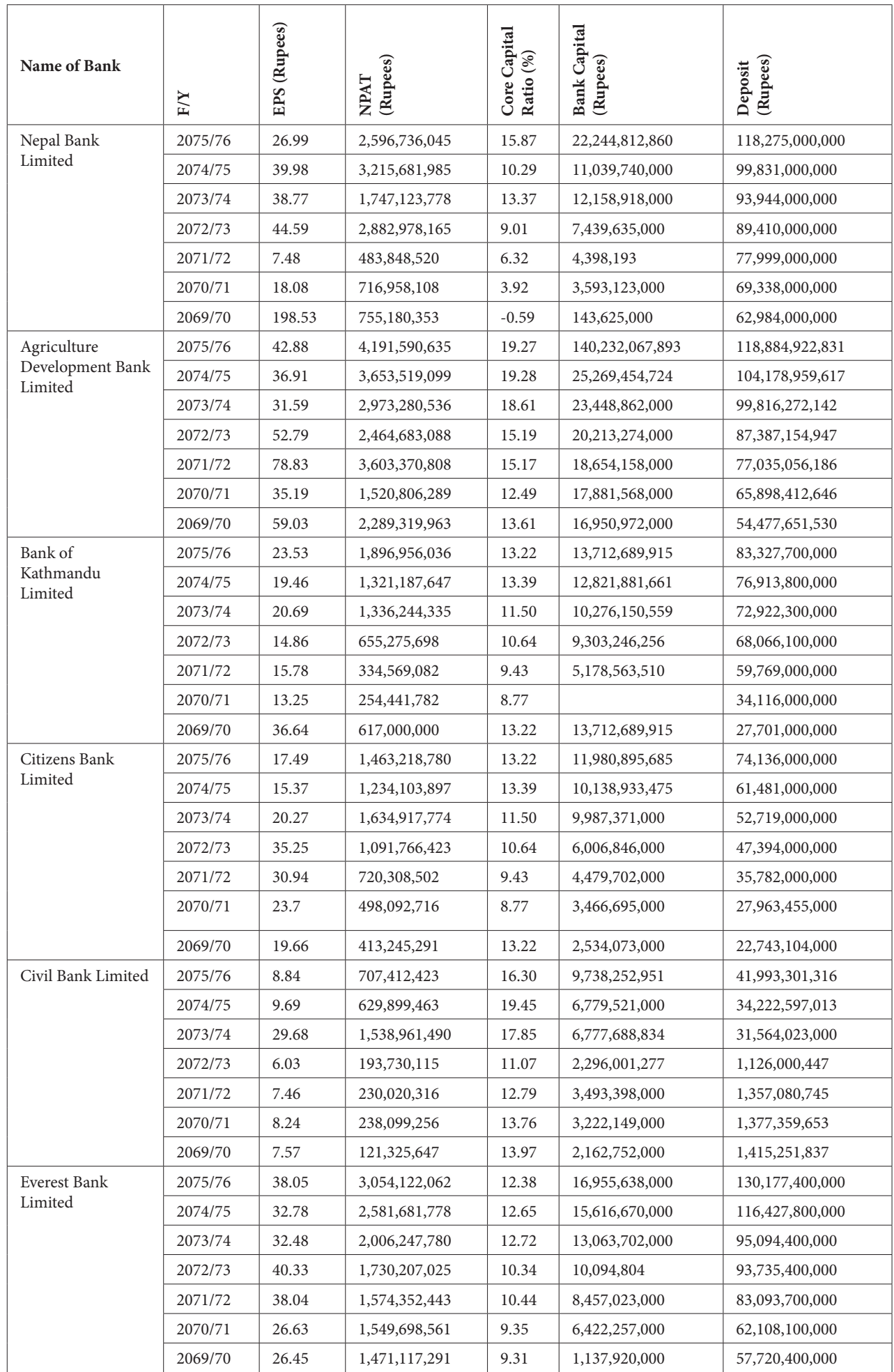




\begin{tabular}{|c|c|c|c|c|c|c|}
\hline Name of Bank & $\sum_{I I}$ & 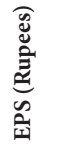 & 息 & 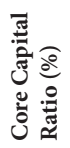 & 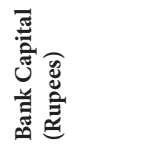 & 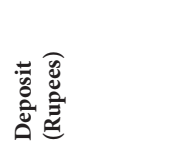 \\
\hline \multirow{7}{*}{$\begin{array}{l}\text { Global IME Bank } \\
\text { Limited }\end{array}$} & $2075 / 76$ & 26.79 & $2,761,953,667$ & 10.56 & $17,350,622,000$ & $124,499,000,000$ \\
\hline & $2074 / 75$ & 23.64 & $2,101,363,149$ & 10.32 & & $106,510,000,000$ \\
\hline & $2073 / 74$ & 25.51 & $2,006,159,460$ & 10.23 & $11,543,265,922$ & $101,910,000,000$ \\
\hline & $2072 / 73$ & 19.33 & $1,382,223,998$ & 11.01 & $9,381,257,819$ & $74,683,000,000$ \\
\hline & $2071 / 72$ & 15.58 & $960,608,067$ & 11.24 & $7,908,636,000$ & $60,176,000,000$ \\
\hline & $2070 / 71$ & 19.57 & $974,037,010$ & 10.94 & $6,805,535,114$ & $52,292,000,000$ \\
\hline & $2069 / 70$ & 16.15 & $449,218,454$ & 9.17 & $3,874,581,100$ & $34,111,000,000$ \\
\hline \multirow{7}{*}{$\begin{array}{l}\text { Himalayan Bank } \\
\text { Limited }\end{array}$} & $2075 / 76$ & 32.44 & $2,763,848,475$ & 11.63 & $15,871,587,201$ & $113,090,000,000$ \\
\hline & $2074 / 75$ & 23.11 & $1,875,610,467$ & 11.40 & $14,349,498,457$ & $99,743,000,000$ \\
\hline & $2073 / 74$ & 33.55 & $2,178,234,893$ & 10.93 & $12,613,817,027$ & $92,881,114,255$ \\
\hline & $2072 / 73$ & 43.03 & $1,935,907,634$ & 10.93 & $9,815,198,969$ & $87,335,785,849$ \\
\hline & $2071 / 72$ & 33.37 & $1,112,285,716$ & 9.43 & $8,041,967,083$ & $73,538,200,185$ \\
\hline & $2070 / 71$ & 33.1 & $959,107,241$ & 9.48 & $7,155,579,476$ & $64,674,848,295$ \\
\hline & $2069 / 70$ & 34.19 & $943,697,990$ & 8.96 & $6,414,437,452$ & $53,072,319,487$ \\
\hline \multirow{7}{*}{$\begin{array}{l}\text { Kumari Bank } \\
\text { Limited }\end{array}$} & $2075 / 76$ & 14.81 & $1,230,378,260$ & 10.89 & $11,432,900,000$ & $84,403,000,000$ \\
\hline & $2074 / 75$ & 14.54 & $1,046,488,403$ & 12.48 & $10,462,927,000$ & $69,651,000,000$ \\
\hline & $2073 / 74$ & 13.29 & $793,142,994$ & 13.55 & & $52,037,000,000$ \\
\hline & $2072 / 73$ & 26.53 & $716,064,646$ & 10.75 & $4,259,079,000$ & $37,951,000,000$ \\
\hline & $2071 / 72$ & 16.24 & $394,788,376$ & 9.89 & $3,525,690,000$ & $33,422,000,000$ \\
\hline & $2070 / 71$ & 18.69 & $341,654,966$ & 10.85 & $3,185,508,000$ & $27,578,000,000$ \\
\hline & $2069 / 70$ & 18.17 & $291,448,365$ & 11.24 & $2,850,138,000$ & $25,319,000,000$ \\
\hline \multirow{7}{*}{$\begin{array}{l}\text { Laxmi Bank } \\
\text { Limited }\end{array}$} & $2075 / 76$ & 17.82 & $1,590,074,275$ & 11.01 & $12,269,000,000$ & $84,403,000,000$ \\
\hline & $2074 / 75$ & 14.37 & $1,181,090,925$ & 11.32 & $10,987,000,000$ & $69,651,000,000$ \\
\hline & $2073 / 74$ & 21.77 & $1,006,624,170$ & 12.43 & $9,986,117,000$ & $52,037,000,000$ \\
\hline & $2072 / 73$ & 27.15 & $677,127,177$ & 9.79 & $6,075,527,000$ & $37,951,000,000$ \\
\hline & $2071 / 72$ & 19.42 & $416,195,924$ & 9.17 & $4,634,659,000$ & $33,422,000,000$ \\
\hline & $2070 / 71$ & 26.07 & $474,856,488$ & 10.85 & $3,697,912,000$ & $27,578,000,000$ \\
\hline & $2069 / 70$ & 24.78 & $419,842,579$ & 11.24 & $3,262,640,000$ & $25,319,000,000$ \\
\hline \multirow{7}{*}{$\begin{array}{l}\text { Machhapuchchhre } \\
\text { Bank Limited }\end{array}$} & $2075 / 76$ & 21.07 & $1,697,088,243$ & 11.88 & $11,308,458,000$ & $91,560,200,000.00$ \\
\hline & $2074 / 75$ & 15.81 & $1,249,688,316$ & 14.38 & $10,623,725,000$ & $72,474,719,641$ \\
\hline & $2073 / 74$ & 24 & $1,302,483,429$ & 15.78 & $9,091,177,000$ & $58,629,076,680$ \\
\hline & $2072 / 73$ & 25.04 & $898,222,681$ & 11.32 & $5,726,052,792$ & $52,291,877,270$ \\
\hline & $2071 / 72$ & 22.2 & $616,372,739$ & 11.14 & $4,351,914,904$ & $44,205,637,252$ \\
\hline & $2070 / 71$ & 18.34 & $454,687,791$ & 9.69 & $3,456,483,000$ & $37,132,092,928$ \\
\hline & $2069 / 70$ & 5.98 & $148,599,200$ & 11.59 & $2,923,876,000$ & $27,136,654,448$ \\
\hline \multirow{7}{*}{$\begin{array}{l}\text { Megha Bank } \\
\text { Limited }\end{array}$} & $2075 / 76$ & 15.69 & $1,629,689,787$ & 14.34 & $13,598,590,000$ & $81,859,000,000$ \\
\hline & $2074 / 75$ & 12.81 & $1,317,351,773$ & 16.97 & $12,568,650,000$ & $62,965,000,000$ \\
\hline & $2073 / 74$ & 17.31 & $793,006,074$ & 13.8 & $6,195,945,544$ & $38,937,000,000$ \\
\hline & $2072 / 73$ & 17 & $551,043,663$ & 11.94 & $4,469,681,000$ & $30,750,000,000$ \\
\hline & $2071 / 72$ & 13.27 & $346,296,108$ & 13.98 & $3,254,691,000$ & $21,131,000,000$ \\
\hline & $2070 / 71$ & 13.11 & $305,537,370$ & 15.24 & $2,888,264,000$ & $17,148,000,000$ \\
\hline & $2069 / 70$ & 7.61 & $177,355,953$ & 17.24 & $2,566,849,000$ & $12,533,000,000$ \\
\hline
\end{tabular}




\begin{tabular}{|c|c|c|c|c|c|c|}
\hline Name of Bank & 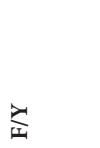 & 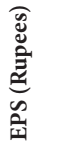 & 㫐芯 & 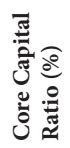 & 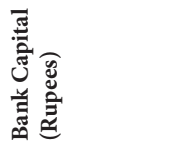 & 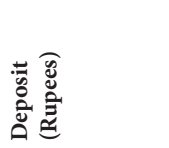 \\
\hline \multirow{7}{*}{$\begin{array}{l}\text { Nabil Bank } \\
\text { Limited }\end{array}$} & $2075 / 76$ & 50.57 & $4,238,853,581$ & 11.40 & $21,245,470,606$ & $164,373,041,697$ \\
\hline & $2074 / 75$ & 49.51 & $3,981,892,950$ & 11.51 & $18,710,876,440$ & $135,979,364,610$ \\
\hline & $2073 / 74$ & 59.86 & $3,613,200,322$ & 11.21 & $14,752,638,819$ & $118,684,419,344$ \\
\hline & $2072 / 73$ & 59.27 & $2,819,333,752$ & 10.51 & $12,203,615,000$ & $110,210,927,524$ \\
\hline & $2071 / 72$ & 57.24 & $2,093,813,608$ & 10.18 & $10,154,006,000$ & $104,237,910,083$ \\
\hline & $2070 / 71$ & 83.68 & $2,319,557,472$ & 9.68 & $8,302,904,000$ & $75,388,790,862$ \\
\hline & $2069 / 70$ & 91.05 & $2,226,686,260$ & 9.98 & $7,366,908,000$ & $63,506,102,707$ \\
\hline \multirow{7}{*}{$\begin{array}{l}\text { Nepal Bangladesh } \\
\text { Bank Limited }\end{array}$} & $2075 / 76$ & 19.63 & $1,587,960,145$ & 11.06 & $14,202,230,000.00$ & $59,764,707,000$ \\
\hline & $2074 / 75$ & 14.95 & $1,144,035,276$ & 13.31 & $11,628,900,000$ & $47,982,823,000$ \\
\hline & $2073 / 74$ & 28.05 & $1,200,381,901$ & 14.39 & $10,715,863,000$ & $43,713,193,739$ \\
\hline & $2072 / 73$ & 39.43 & $1,198,297,230$ & 10.21 & $6,042,450,000$ & $39,874,233,993$ \\
\hline & $2071 / 72$ & 33.48 & $813,976,568$ & 10.6 & $4,848,885,000$ & $33,832,696,025$ \\
\hline & $2070 / 71$ & 36.94 & $742,342,538$ & 10.64 & $3,612,011,000$ & $25,706,915,697$ \\
\hline & $2069 / 70$ & 38.75 & $778,645,431$ & 10.76 & $2,664,288,000$ & $17,845,158,014$ \\
\hline \multirow{7}{*}{$\begin{array}{l}\text { Nepal Credit and } \\
\text { Commerce Bank } \\
\text { Limited }\end{array}$} & $2075 / 76$ & 15.77 & $1,021,232,240$ & 13.38 & $11,887,310,000$ & \\
\hline & $2074 / 75$ & 23.51 & $1,341,516,334$ & 10.29 & $7,571,000,000$ & $63,430,544,471$ \\
\hline & $2073 / 74$ & 14.02 & $505,867,992$ & 9.75 & $6,273,732,729$ & $58,795,094,314$ \\
\hline & $2072 / 73$ & 30.08 & $707,840,700$ & 11.08 & $3,927,019,409$ & $30,363,555,060$ \\
\hline & $2071 / 72$ & 17.17 & $348,254,007$ & 10.45 & $3,019,711,175$ & $26,661,129,863$ \\
\hline & $2070 / 71$ & 26.67 & $392,111,964$ & 10.70 & $2,562,362,682$ & $22,256,871,407$ \\
\hline & $2069 / 70$ & 24.14 & $354,827,828$ & 10.90 & $2,297,805,464$ & $21,651,267,380$ \\
\hline \multirow{7}{*}{$\begin{array}{l}\text { Nepal Investment } \\
\text { Bank Limited }\end{array}$} & $2075 / 76$ & 26.4 & $3,324,112,936$ & 11.39 & $26,235,893,404$ & $152,183,000,000$ \\
\hline & $2074 / 75$ & 35.7 & $3,659,322,725$ & 11.58 & $22,695,798,460$ & $140,328,000,000$ \\
\hline & $2073 / 74$ & 29.3 & $3,114,131,140$ & 11.58 & $20,367,202,860$ & $125,669,000,000$ \\
\hline & $2072 / 73$ & 29.3 & $2,550,883,563$ & 13.05 & $18,182,543,651$ & $108,626,000,000$ \\
\hline & $2071 / 72$ & 30.9 & $1,961,852,380$ & 9.54 & $11,754,293,710$ & $90,631,000,000$ \\
\hline & $2070 / 71$ & 40.7 & $1,939,612,344$ & 9.52 & $8,993,849,000$ & $73,831,000,000$ \\
\hline & $2069 / 70$ & 46.2 & $1,915,027,932$ & 10.01 & $7,813,057,000$ & $62,429,000,000$ \\
\hline \multirow{7}{*}{$\begin{array}{l}\text { NIC Asia Bank } \\
\text { Limited }\end{array}$} & $2075 / 76$ & 34.22 & $3,023,282,666$ & 8.24 & $21,804,000,000$ & $180,575,000,000$ \\
\hline & $2074 / 75$ & 16.62 & $1,334,861,927$ & 8.66 & $15,350,010,000$ & $151,219,000,000$ \\
\hline & $2073 / 74$ & 23.06 & $1,473,465,967$ & 12.38 & $10,912,194,316$ & $86,679,102,631$ \\
\hline & $2072 / 73$ & 28.31 & $1,066,906,232$ & 10.69 & $9,193,013,294$ & $69,487,997,265$ \\
\hline & $2071 / 72$ & 25.59 & $680,317,101$ & 10.53 & $6,059,261,071$ & $53,477,184,239$ \\
\hline & $2070 / 71$ & 35.98 & $831,588,872$ & 11.84 & $5,725,861,568$ & $44,984,218,467$ \\
\hline & $2069 / 70$ & 47.41 & $642,136,406$ & 12.21 & $4,693,288,345$ & $39,908,774,213$ \\
\hline \multirow[t]{7}{*}{ NMB Bank } & $2075 / 76$ & 23.54 & $2,257,276,027$ & 13.09 & $19,061,375,000$ & $98,516,667,000$ \\
\hline & $2074 / 75$ & 21.86 & $1,853,792,753$ & 14.78 & $16,851,254,000$ & $84,507,136,000$ \\
\hline & $2073 / 74$ & 22.24 & $1,467,347,467$ & 12.39 & $11,393,685,000$ & $73,224,063,000$ \\
\hline & $2072 / 73$ & 22.1 & $1,115,064,628$ & 9.34 & $7,790,514,000$ & $64,781,464,000$ \\
\hline & $2071 / 72$ & 21.48 & $500,989,608$ & 8.84 & $3,982,873,000$ & $36,723,000,000$ \\
\hline & $2070 / 71$ & 20.5 & $409,922,982$ & 9.91 & $2,918,892,000$ & $27,087,000,000$ \\
\hline & $2069 / 70$ & 18.02 & $360,393,624$ & 10.42 & $2,489,383,000$ & $22,186,000,000$ \\
\hline
\end{tabular}




\begin{tabular}{|c|c|c|c|c|c|c|}
\hline Name of Bank & $\underset{I}{T}$ & 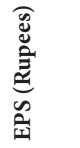 & 息 & 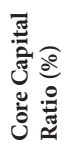 & 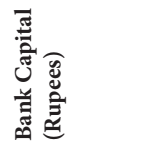 & 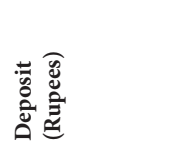 \\
\hline \multirow{7}{*}{$\begin{array}{l}\text { Prabhu Bank } \\
\text { Limited }\end{array}$} & $2075 / 76$ & 21.03 & $1,783,592,538$ & 10.22 & $13,148,762,968$ & $112,393,448,000$ \\
\hline & $2074 / 75$ & 12.58 & $967,034,844$ & 10.82 & $11,430,641,456$ & $97,259,665,000$ \\
\hline & $2073 / 74$ & 27.17 & $1,597,952,553$ & 9.45 & $8,504,116,199$ & $81,349,540,000$ \\
\hline & $2072 / 73$ & 26.75 & $1,117,363,714$ & 10.62 & $6,985,571,384$ & $60,940,868,000$ \\
\hline & $2071 / 72$ & 31.73 & $1,018,245,374$ & 9.44 & $583,725,263$ & $42,142,974,000$ \\
\hline & $2070 / 71$ & -15.24 & $-304,851,936$ & 7.65 & $1,088,499,748$ & $19,835,166,000$ \\
\hline & $2069 / 70$ & -40.23 & $-804,628,575$ & 7.62 & $1,571,695,000$ & $21,093,025,000$ \\
\hline \multirow{7}{*}{$\begin{array}{l}\text { Prime Bank } \\
\text { Limited }\end{array}$} & $2075 / 76$ & 23.6 & $2,198,792,243$ & 11.97 & $13,644,465,572$ & $86,257,837,697$ \\
\hline & $2074 / 75$ & 21.49 & $1,726,246,109$ & 11.43 & $11,659,258,818$ & $81,304,476,188$ \\
\hline & $2073 / 74$ & 23.21 & $1,467,942,925$ & 12.45 & $9,937,824,828$ & $65,855,880,385$ \\
\hline & $2072 / 73$ & 30.11 & $1,115,759,677$ & 10.76 & $5,776,701,505$ & $48,342,121,058$ \\
\hline & $2071 / 72$ & 23.74 & $745,589,121$ & 11.29 & $4,624,956,603$ & $41,005,754,566$ \\
\hline & $2070 / 71$ & 20.97 & $553,447,114$ & 11.53 & $3,888,556,422$ & $34,045,262,660$ \\
\hline & $2069 / 70$ & 18.55 & $477,566,263$ & 11.88 & $3,164,222,000$ & $28,798,028,030$ \\
\hline \multirow{7}{*}{$\begin{array}{l}\text { Sanima Bank } \\
\text { Limited }\end{array}$} & $2075 / 76$ & 28.22 & $2,258,067,506$ & 10.63 & $13,364,410,000$ & $92,140,000,000$ \\
\hline & $2074 / 75$ & 21.22 & $1,697,503,224$ & 11.14 & $10,889,090,000$ & $79,139,000,000$ \\
\hline & $2073 / 74$ & 26.31 & $1,304,103,406$ & 14.07 & $9,870,186,114$ & $57,754,000,000$ \\
\hline & $2072 / 73$ & 32.55 & $996,054,127$ & 10.69 & $6,039,446,132$ & $46,344,000,000$ \\
\hline & $2071 / 72$ & 24.47 & $624,141,298$ & 10.13 & $3,734,498,766$ & $34,045,316,000$ \\
\hline & $2070 / 71$ & 19.28 & $427,595,604$ & 11.52 & $3,072,172,121$ & $24,873,849,000$ \\
\hline & $2069 / 70$ & 15.13 & $305,061,132$ & 13.91 & $2,565,034,704$ & $17,789,329,000$ \\
\hline \multirow[t]{7}{*}{ SBI Bank Limited } & $2075 / 76$ & 27.13 & $2,292,524,396$ & 12.72 & $14,804,827,617$ & $97,924,400,000$ \\
\hline & $2074 / 75$ & 25.16 & $2,023,511,124$ & 13.38 & $13,728,773,698$ & $84,269,200,000$ \\
\hline & $2073 / 74$ & 33.46 & $1,523,237,401$ & 13.53 & $11,692,078,000$ & $81,664,548,665$ \\
\hline & $2072 / 73$ & 36.78 & $1,331,881,801$ & 10.98 & $8,169,663,000$ & $65,213,519,724$ \\
\hline & $2071 / 72$ & 34.48 & $1,065,436,141$ & 11.18 & $7,063,688,000$ & $51,628,221,954$ \\
\hline & 2070/71 & 34.83 & $922,984,007$ & 10.19 & $5,892,028,000$ & $54,492,993,606$ \\
\hline & $2069 / 70$ & 32.75 & $771,471,129$ & 9.59 & $4,888,637,991$ & $58,920,455,656$ \\
\hline \multirow{7}{*}{$\begin{array}{l}\text { Standard Char- } \\
\text { tered Bank Limited }\end{array}$} & $2075 / 76$ & 30.39 & $2,434,664,521$ & 18.31 & $14,971,059,954$ & $75,731,527,432.00$ \\
\hline & $2074 / 75$ & 27.33 & $2,189,898,090$ & 21.41 & $13,986,845,583$ & $67,061,046,522.00$ \\
\hline & $2073 / 74$ & 35.49 & $1,421,596,136$ & 19.58 & $11,975,101,524$ & $63,872,885,000.00$ \\
\hline & $2072 / 73$ & 45.96 & $1,292,494,632$ & 14.08 & $7,779,409,000$ & $55,727,178,000.00$ \\
\hline & $2071 / 72$ & 57.38 & $1,290,025,348$ & 11.67 & $6,111,788,000$ & $57,286,482,000.00$ \\
\hline & 2070/71 & 65.47 & $1,336,589,187$ & 10.83 & $5,333,516,000$ & $46,298,532,000$ \\
\hline & $2069 / 70$ & 65.7 & $1,217,940,751$ & 11.03 & $4,828,551,000$ & $39,466,453,000$ \\
\hline \multirow{7}{*}{$\begin{array}{l}\text { Siddhartha Bank } \\
\text { Limited }\end{array}$} & $2075 / 76$ & 26 & $2,257,688,323$ & 10.19 & $16,953,951,000$ & $122,527,700,000$ \\
\hline & $2074 / 75$ & 26.45 & $1,904,061,504$ & 10.99 & $13,187,005,000$ & $101,748,200,000$ \\
\hline & $2073 / 74$ & 26.6 & $1,386,175,502$ & 11.02 & $10,717,460,000$ & $77,316,600,000$ \\
\hline & $2072 / 73$ & 41.53 & $1,254,918,004$ & 8.78 & $7,708,558,000$ & $64,934,400,000$ \\
\hline & $2071 / 72$ & 37.77 & $767,080,512$ & 7.58 & $5,244,638,000$ & $44,740,730,000.00$ \\
\hline & $2070 / 71$ & 38.63 & $700,534,999$ & 8.39 & $3,995,774,000$ & $35,414,010,000.00$ \\
\hline & $2069 / 70$ & 29.8 & $482,556,447$ & 8.21 & $3,513,565,000$ & $28,392,820,000.00$ \\
\hline
\end{tabular}


The Impact of Capital and Deposit on Financial Performance of Commercial Banks in Nepal

\begin{tabular}{|c|c|c|c|c|c|c|}
\hline Name of Bank & $\underset{I}{\Delta}$ & 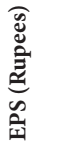 & 忎 & 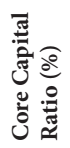 & 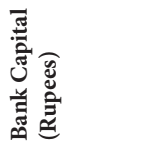 & 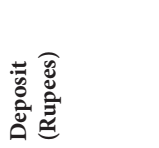 \\
\hline \multirow{7}{*}{$\begin{array}{l}\text { Sunrise Bank } \\
\text { Limited }\end{array}$} & $2075 / 76$ & 20.94 & $1,706,102,088$ & 11.37 & $12,722,042,072$ & $78,740,000,000$ \\
\hline & $2074 / 75$ & 18.13 & $1,476,971,853$ & 12.59 & $10,925,126,067$ & $69,480,000,000$ \\
\hline & $2073 / 74$ & 16.76 & $1,112,851,929$ & 13.39 & $9,854,712,000$ & $61,013,263,534$ \\
\hline & $2072 / 73$ & 23.93 & $951,378,476$ & 11.13 & $6,541,746,000$ & $51,650,280,064$ \\
\hline & $2071 / 72$ & 19.27 & $470,857,056$ & 10.11 & $3,612,062,000$ & $33,486,669,059$ \\
\hline & $2070 / 71$ & 11.03 & $246,772,655$ & 10.69 & $2,874,243,000$ & $26,616,667,279$ \\
\hline & $2069 / 70$ & 15.46 & $311,609,037$ & 10.96 & $2,600,252,000$ & $23,270,603,296$ \\
\hline \multirow{7}{*}{$\begin{array}{l}\text { Century Bank } \\
\text { Limited }\end{array}$} & $2075 / 76$ & 8.04 & $676,407,831$ & 13.46 & $10,170,770,000$ & $65,488,597,980$ \\
\hline & $2074 / 75$ & 11.31 & $912,283,372$ & 13.65 & $9,586,970,000$ & $61,321,550,155$ \\
\hline & $2073 / 74$ & 9.18 & $501,365,807$ & 13.91 & $6,665,547,473$ & $42,593,653,750$ \\
\hline & $2072 / 73$ & 14.56 & $413,533,271$ & 11.90 & $3,648,392,000$ & $28,967,846,551$ \\
\hline & $2071 / 72$ & 12.3 & $260,864,190$ & 10.35 & $2,603,332,000$ & $24,948,567,976$ \\
\hline & $2070 / 71$ & 6.15 & $86,927,673$ & 13.17 & $2,305,815,000$ & $18,393,723,078$ \\
\hline & $2069 / 70$ & 0.09 & $66,371,596$ & 11.78 & $1,309,096,335$ & $11,396,473,762$ \\
\hline
\end{tabular}

